\title{
Development of Methodological Foundations for Stating the Cost of Agricultural Products
}

\author{
Polikarpova E.P.* \\ Ryazan State Agrotechnological University Named after \\ P.A. Kostychev \\ Ryazan, Russia \\ e-mail: Dikusar85@mail.ru
}

\author{
Mizikovskiy I.E. \\ Lobachevsky State University of Nizhny Novgorod \\ Nizhny Novgorod, Russia
}

\begin{abstract}
The key task of managing the production of a modern economic entity is to minimize the labor product cost. Its value, in turn, is determined by choosing the method of cost accounting and calculating the labor product cost, depending on characteristics of the production process. The current methodological approach to planning production costs and the use of calculated indicators does not meet agricultural conditions and requires significant adjustments. The proposed reorientation of the general methodological approach to planning and cost accounting and determining the cost of agricultural production involves fundamental changes in determining reporting periods of production. The article substantiates the need to revise the timing of the implementation of budget, provisory and actual costing in agricultural organizations. An example of the preparation and adjustment of the cost budget of production costs is presented, which may be used to prepare the relevant budget documentation. The implementation of the proposed approach helps to improve the accuracy of accounting information about the planned and actual cost and will also make optimization and efficiency of control functions and management decisions possible.
\end{abstract}

Keywords - statement of agricultural products' cost; cost budget; provisory costing; actual costing; long production cycle.

\section{INTRODUCTION}

According to the Concept of accounting in the market economy of Russia in relation to information for internal users, the purpose of accounting is to generate information that is useful for the organization's management to make management decisions.

In the accounting system, economic information is generated about events and facts of economic activity, the nature and total of which, in turn, are largely determined by specific management decisions.

The relevance of accounting records is ensured by the use of an appropriate tool base for processing primary data. The formation of guidance material in management accounting is inextricably linked with the instrumental base of management. In turn, the information processing technique in an economic entity should be applied within the framework of generally accepted legal norms (Fig. 1).

The instrumental base of accounting in the activity of a separate economic subject is specified in the in-house organizational and administrative documentation, which contains instructions for performing the functions of an accounting employee.

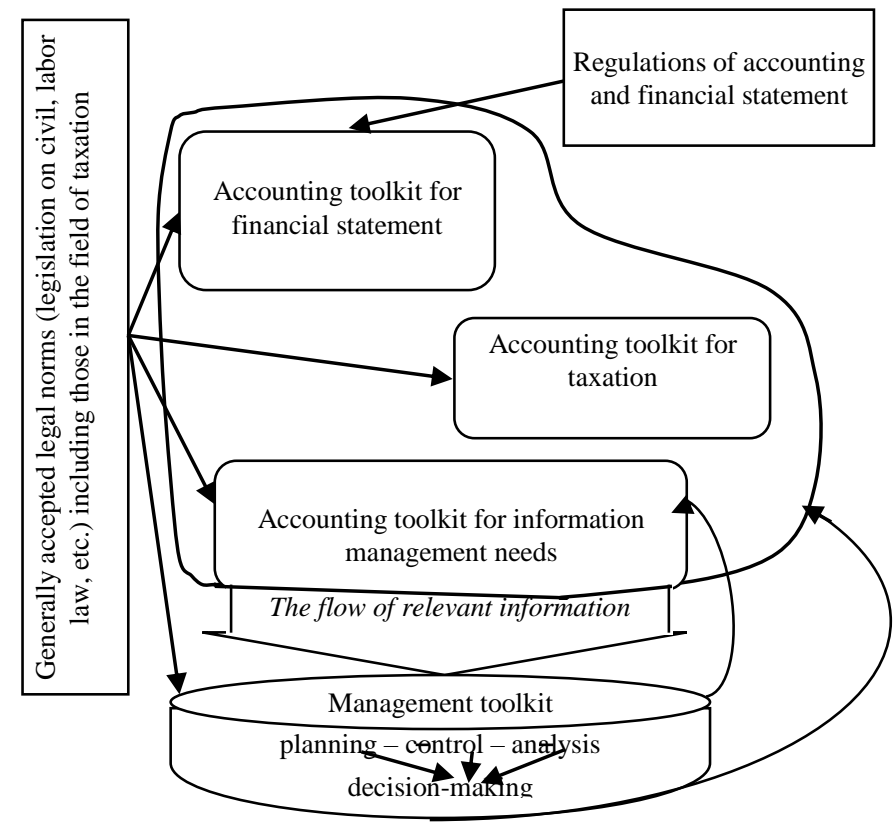

Fig. 1. Instructive sources to form the instrumental base of accounting of an economic entity

The establishment of clear instructions for accountants in the enterprise in order to prepare financial statements or taxation often requires independent choice or development of techniques and methods in view of the multivariance or lack of specification on issues regulated at a higher regulatory level.

The relevance of management information for the needs of managing an economic entity determines the greatest concretization of accounting tools, provided by the results of estimated and other planning, control, analysis and, ultimately, management decisions [1-3].

One of the key tasks of strategic production management of a modern economic entity is to minimize the labor product cost. At the same time, the regulation of cost accounting and determination of its value does not represent severe restrictions. Existing industry instructions are indicative.

The choice of the method of cost accounting and calculating the labor product cost depends on a detailed approach to production management, which, in turn, is based 
on the features of the production process. A modern approach to the formation and use of the cost of production indicator is presented in Figure 2.

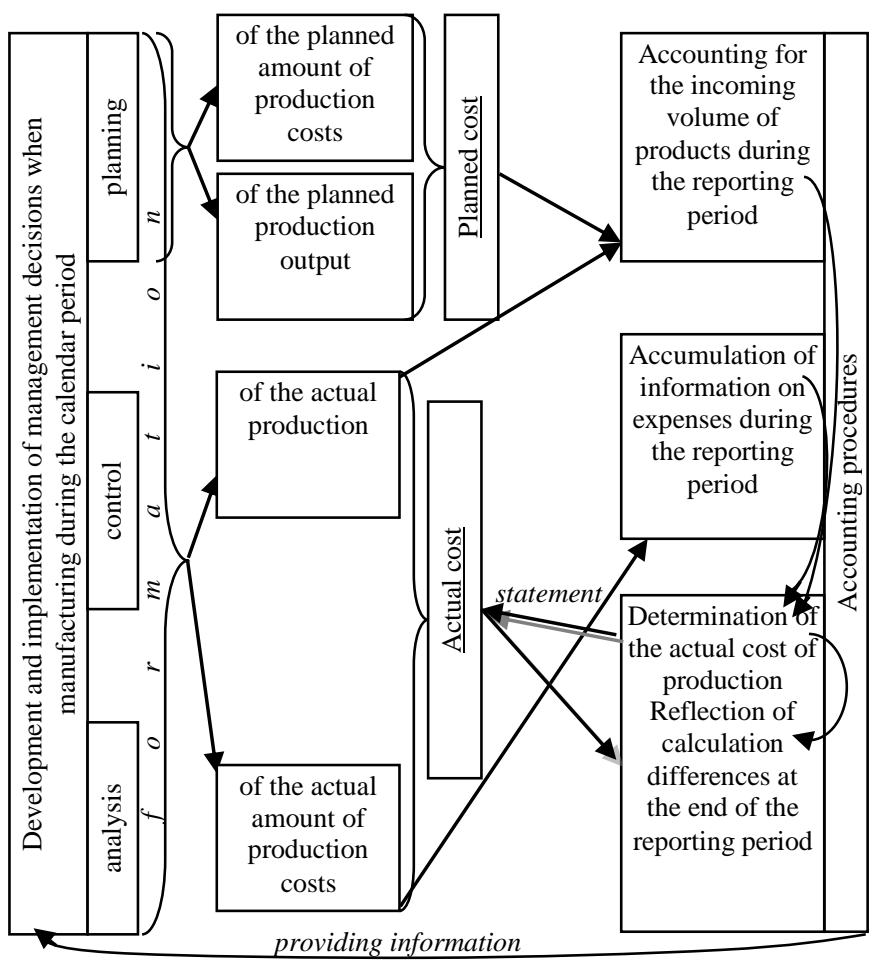

Fig. 2. The generally accepted procedure for the formation and use of an indicator of the cost of production in the process of performing accounting and management procedures

The approach under consideration involves the statement of the planned and (or) normative cost of a labor product at the beginning of the reporting period - a calendar month, quarter or year. Further, during the reporting period, accounting information is accumulated on the costs incurred in accordance with the adopted production technology and relevant management decisions and the volume of products produced, estimated at the planned (normative) cost. The specified information stands for operational information to monitor and analyze costs. At the end of the accounting period, the actual cost of the statement object is determined, the statement differences are presented, which also generates information for management needs.

It seems that the approach under consideration is optimal in industrial production sectors, which are characterized by a relatively short duration of production cycles and sufficient certainty of the expected production output (according to the technology used) even at the stage of production planning [4].

In order to determine the planned cost of production, cost budget is made at the beginning of the planning period according to current industry recommendations, on the basis of which there is a modern practice of cost accounting. For most types of agricultural products, the calendar year is set as the planning period, except for protected vegetables (both average quarterly and monthly costs can be planned for them).
In addition, based on the need to calculate the actual cost of production (work, services) in agricultural organizations after the completion of the production cycle, industry recommendations establish the frequency of costing statements of crop and livestock production after a calendar year. Exceptions are protected vegetables and fine-wooled sheep products. Given the frequency of sheep shearing - once a year (usually in June), offspring (February - March) and separation of lambs from sheep (June), it is advisable to calculate wool and offspring according to industry recommendations not at the end of the year, but at the end of the first phase of the production process, that is in July.

Russian regulatory documents provide for the possibility of agricultural provisory costing by agricultural organizations during the calendar year to determine the expected cost of production. To do this, actual production accounting data and preliminary statements of expected production results (costs and output) are used. A large control value of the expected cost is accentuated from the point of view of the strategically important direction of the enterprise's management work to reduce production costs. However, it is understood that the provisory statement is carried out at the end of a calendar month (quarter), usually September for the whole product (crop production, as a rule), regardless of the expected or actual moment of the end of the production cycle of a particular crop.

At the same time, the estimated cost of production is not provided for the valuation of manufactured products at the time of their recognition. Accountants present the receipt of finished products during the calendar year at the planned cost.

For its statement, industry recommendations provide for the preparation of a planned statement based on the planned norms of production costs and other planned indicators (crop yields, etc.). At the same time, data of industrial accounting and production costs for previous years are used, and the norms of material and labor costs should be justified (progressive).

\section{RESULTS AND DISCUSSION}

The results of the study of the organization and the procedure for implementing managerial work in agricultural organizations have shown, for the most part, the absence of an integrated approach to setting up a management system and its interaction with accounting processes at the enterprise. To evaluate finished products during the calendar year, accountants usually use the planned cost equal to the actual cost of the last year production. Planned and provisory statements are not made.

Achieving and improving the efficiency of the production organization is ensured by implementation of strategic management tasks. Minimizing the cost of production is one of the main ones [5, 6]. Obviously, the lack of a clearly established and perfect controlling system in agricultural production, including constructive accounting and information space for making managerial decisions, causes a number of problems in ensuring high work efficiency. However, the current methodological approach to planning of production 
costs and the use of calculated indicators does not meet the conditions of agriculture and requires significant adjustment.

Unlike industry, the impact of biological characteristics of agricultural production [7-12] causes forced changes in the technology or results of production during and at the end of a long production cycle [13-15], which limits the possibility of accurate planning of costs and production output at the beginning of the reporting period (usually a calendar year).

A striking example of this problem is the degree of accuracy in determining the planned cost of a unit of production of winter crops at the beginning of the calendar year, when a part of the production costs has already been actually implemented, but the production cycle has just begun and there are still several months before the products appear. The low level of reliability of the statement result is due to high uncertainty of the level of exposure to expected (and unexpected) natural factors during the upcoming period of crop cultivation at the time of its maturation and in the period preferable for harvesting. The production cycle for growing spring crops begins a few months after the calendar year and ends a few months later, which by analogy with winter crops, leads to a low degree of accuracy in determining the planned cost of the unit of production at the beginning of the year.

In the livestock industry, offspring is an example of products from a long production cycle [16, 17]. At the beginning of a calendar year it may be the middle, beginning, end or any moment of the period of its production for a particular animal. Besides, the production cycle for individual animals can begin a few months after the calendar year, and end, respectively, either in the current or next year. Obviously, the generally accepted methodology for determining the planned unit cost of a specified product (in particular, the moment and object of statement) does not provide high reliability and accuracy of the statement result because of peculiar biological processes.

Therefore, for agricultural organizations engaged in the production of long-cycle products, a fundamental adjustment of the general approach to the formation and use of production costs from the position of accounting and management procedures is required (Fig. 3).

From the point of view of time periods, the planning of costs and crop production output (with the exception of protected ground) starts from the moment of determining and preparing the area of agricultural land allocated for a particular crop. For winter crops, the corresponding work is carried out in autumn months. Thus, initial cost budget can be made in late August - early September, even before the beginning of the next calendar year. In the indicated period, agricultural land areas are prepared for growing spring crops in the next calendar year, but the final allocation of areas and planning of costs and production output of specific products is carried out by the beginning of the production cycle of each of them (spring months of next year).

Thus, the period immediately before the start of the production cycle is the most appropriate period for the corresponding management procedures to prepare planned (initial) statements. At the same time, cost indicators should be detailed not only by articles, but also by separate phases of production and months, which will ensure compatibility of accounting information for comparing and analyzing actual and planned indicators during the production cycle. Rational control in this case can be provided by the process of reserving costs [13]

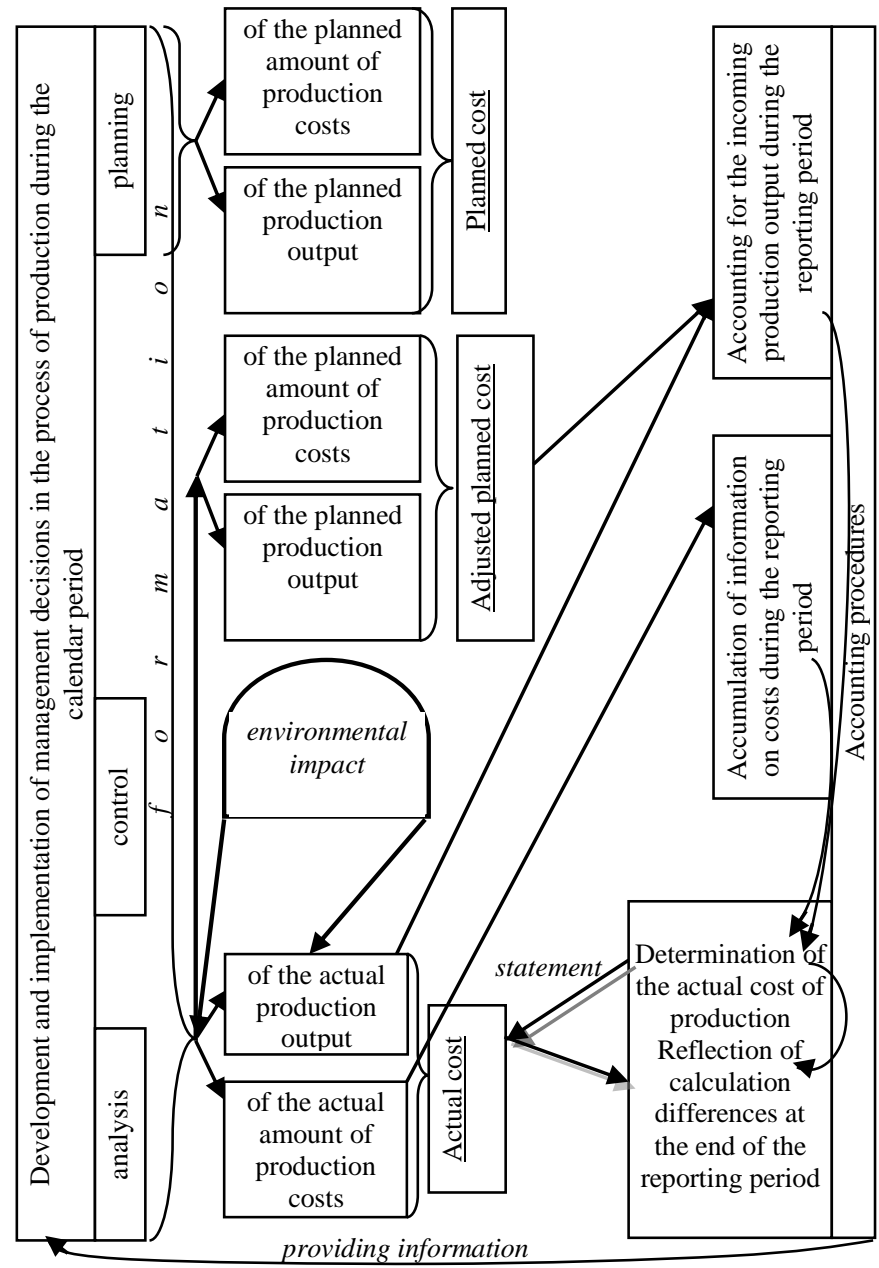

Fig. 3. The proposed approach to the formation and use of the cost of production in the process of accounting and management procedures

The duration of the production cycle in conjunction with the impact of natural conditions of activity leads to a significant decrease in the importance of applying the initial planned cost to evaluate an agricultural product at the time of its capitalization from production.

It is most rational for this to make provisory costing in order to adjust the planned (expected) cost to a more accurate value. Its use will increase the reliability of accounting information on the production output and reduce the value of the statement differences.

In addition, it seems essential to transfer the moment of determining the actual production cost of the manufactured products from the end of the calendar year (actually later) to the end of the month in which the products of a particular type (group) are capitalized in full from the production. 
The proposed reorientation of the general methodological approach to costs planning and accounting and determining the cost of agricultural products involves fundamental changes in determining reporting periods of production.

In this regard, the reporting period should be set separately for the production of a specific type (group) of products, depending on natural time periods for its production. Specific species (groups) are predetermined. For example, crops are optimally grouped according to the principal varietal characteristics of cultivation and peculiarities of the agricultural area planned for cultivation of the corresponding crop.

Table 1 presents the example of compiling and adjusting the planned costing of spring barley production. The presented sections of the tables are perfect for the preparation of the relevant planning documentation. The same register has details information on actual costs and cost, which ensures the compatibility of information for analysis. It is obvious that the value of the adjusted planned (provisory) cost is more consistent with the actual one, which confirms the rationality of its use for evaluating the finished product when it comes from production.

TABLE I. COSTS PLAN AND CALCULATION OF COST OF PRODUCTION OF SPRING BARLEY VICONT

Field 3-18 Area: sown - 620 ha; harvested -620 ha

1. Calculation of the total cost

\begin{tabular}{|c|c|c|c|c|}
\hline \multirow{2}{*}{ కి } & \multirow{2}{*}{ Cost items } & \multicolumn{2}{|c|}{$\begin{array}{l}\text { Planned amount of } \\
\text { costs, thousand } \\
\text { rubles. }\end{array}$} & \multirow{2}{*}{$\begin{array}{l}\text { Actual } \\
\text { amount of } \\
\text { costs, } \\
\text { thousand } \\
\text { rubles (as of } \\
\text { September } \\
\text { 30, 2018) }\end{array}$} \\
\hline & & $\begin{array}{c}\text { statement } \\
\text { March } \\
20,2018\end{array}$ & \begin{tabular}{|c|} 
adjustme \\
nt July \\
05,2018
\end{tabular} & \\
\hline \multicolumn{2}{|c|}{$\begin{array}{l}\text { Costs to prepare the production of } \\
\text { previous months }\end{array}$} & $2,553.65$ & $2,553.65$ & $2,553.65$ \\
\hline \multirow{11}{*}{ 胥 } & Capital consumption & 205.84 & 205.84 & 205.84 \\
\hline & Fuels and lubricants & 65.32 & 68.20 & 68.20 \\
\hline & $\begin{array}{l}\text { Spare parts, repair and building } \\
\text { materials for repair }\end{array}$ & 35.24 & 33.11 & 33.11 \\
\hline & Labor costs & 45.18 & 48.13 & 48.13 \\
\hline & Social benefits & 13.55 & 14.44 & 14.44 \\
\hline & Other prime costs & 18.65 & 22.05 & 22.05 \\
\hline & $\begin{array}{c}\text { Works and services of third- } \\
\text { parties }\end{array}$ & 13.85 & 12.47 & 12.47 \\
\hline & Mineral and organic fertilizers & 305.85 & 381.64 & 381.64 \\
\hline & Electricity & 15.00 & 15.58 & 15.58 \\
\hline & $\begin{array}{c}\text { The costs of organizing } \\
\text { production and its maintenance }\end{array}$ & 200.00 & 198.98 & 198.98 \\
\hline & Management costs & 110.00 & 114.66 & 114.66 \\
\hline & Total per month & $1,028.48$ & $1,115.1$ & $1,115.1$ \\
\hline \multirow{11}{*}{$\frac{3}{2}$} & Capital consumption & 205.84 & 205.84 & 205.84 \\
\hline & Fuels and lubricants & 149.62 & 166.30 & 166.30 \\
\hline & $\begin{array}{c}\text { Spare parts, repair and } \\
\text { building materials for repair }\end{array}$ & 42.59 & 48.23 & 48.23 \\
\hline & Labor costs & 92.58 & 73.15 & 73.15 \\
\hline & Social benefits & 27.74 & 21.95 & 21.95 \\
\hline & Other prime costs & 20.00 & 17.69 & 17.69 \\
\hline & $\begin{array}{c}\text { Works and services of third- } \\
\text { parties }\end{array}$ & 13.54 & 18.54 & 18.54 \\
\hline & Seeds and planting material & 963.35 & 980.95 & 980.95 \\
\hline & Mineral and organic fertilizers & 53.85 & 58.21 & 58.21 \\
\hline & Electricity & 17.50 & 16.61 & 16.61 \\
\hline & The costs of organizing & 220.00 & 224.17 & 224.17 \\
\hline
\end{tabular}

\begin{tabular}{|c|c|c|c|c|}
\hline & production and its maintenance & \multirow[b]{2}{*}{130.00} & \multirow[b]{2}{*}{136.70} & \multirow[b]{2}{*}{136.70} \\
\hline & Management costs & & & \\
\hline & Total per month & $1,936.61$ & $1,968.34$ & $1,968.34$ \\
\hline \multirow{12}{*}{$\stackrel{\Xi}{\Xi}$} & Capital consumption & 205.84 & 205.84 & 205.84 \\
\hline & Fuels and lubricants & 76.12 & 87.27 & 87.27 \\
\hline & $\begin{array}{l}\text { Spare parts, repair and building } \\
\text { materials for repair }\end{array}$ & 59.13 & 61.09 & 61.09 \\
\hline & Labor costs & 63.15 & 65.45 & 65.45 \\
\hline & Social benefits & 18.95 & 19.64 & 19.64 \\
\hline & Other prime costs & 23.00 & 23.64 & 23.64 \\
\hline & $\begin{array}{l}\text { Works and services of third- } \\
\text { parties }\end{array}$ & 38.95 & 39.45 & 39.45 \\
\hline & Mineral and organic fertilizers & 605.35 & 589.09 & 589.09 \\
\hline & $\begin{array}{c}\text { Plant and animal protection } \\
\text { agents }\end{array}$ & 303.12 & 283.63 & 283.63 \\
\hline & Electricity & 18.30 & 21.82 & 21.82 \\
\hline & $\begin{array}{l}\text { The costs of organizing } \\
\text { production and its maintenance }\end{array}$ & 230.00 & 266.94 & 266.94 \\
\hline & Management costs & 130.00 & 130.91 & 130.91 \\
\hline & Total per month & $1,771.91$ & $1,794.77$ & $1,794.77$ \\
\hline \multirow{11}{*}{ 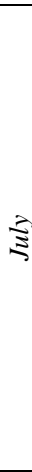 } & Capital consumption & 205.84 & 205.84 & 205.84 \\
\hline & Fuels and lubricants & 278.65 & 278.65 & 290.86 \\
\hline & $\begin{array}{c}\text { Spare parts, repair and } \\
\text { building materials for repair }\end{array}$ & 90.00 & 90.00 & 83.10 \\
\hline & Labor costs & 155.00 & 155.00 & 145.43 \\
\hline & Social benefits & 46.50 & 46.50 & 43.63 \\
\hline & Other prime costs & 30.00 & 30.00 & 41.94 \\
\hline & Works and services of third-parties & 60.00 & 60.00 & 62.27 \\
\hline & $\begin{array}{c}\text { Plant and animal protection } \\
\text { agents }\end{array}$ & 500.85 & 542.56 & 560.90 \\
\hline & Electricity & 19.00 & 19.00 & 20.78 \\
\hline & $\begin{array}{c}\text { The costs of organizing } \\
\text { production and its maintenance }\end{array}$ & 220.00 & 220.00 & 241.00 \\
\hline & Management costs & 130.00 & 130.00 & 137.12 \\
\hline \multirow{11}{*}{$\begin{array}{l}\overline{\mathscr{s}} \\
\vec{b} \\
\vec{z}\end{array}$} & Total per month & $1,735.84$ & $1,777.55$ & $1,832.87$ \\
\hline & Capital consumption & 205.84 & 205.84 & 205.84 \\
\hline & Fuels and lubricants & 708.63 & 736.33 & 740.99 \\
\hline & $\begin{array}{l}\text { Spare parts, repair and building } \\
\text { materials for repair }\end{array}$ & 90.00 & 98.00 & 102.92 \\
\hline & Labor costs & 315.36 & 358.45 & 349.91 \\
\hline & Social benefits & 94.61 & 107.54 & 104.97 \\
\hline & \begin{tabular}{|c|} 
Other prime costs \\
\end{tabular} & 55.00 & 55.00 & 61.75 \\
\hline & Works and services of third-parties & 45.15 & 45.15 & 52.33 \\
\hline & Electricity & 19.00 & 19.00 & 20.58 \\
\hline & $\begin{array}{l}\text { The costs of organizing } \\
\text { production and its maintenance }\end{array}$ & 230.00 & 230.00 & 236.7 \\
\hline & Management costs & 140.00 & 140.00 & 144.08 \\
\hline \multirow{7}{*}{ 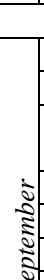 } & Total per month & $1,903.59$ & $1,995.31$ & $2,020.07$ \\
\hline & Capital consumption & 205.84 & 205.84 & 205.84 \\
\hline & Fuels and lubricants & 189.25 & 189.25 & 166.81 \\
\hline & $\begin{array}{c}\text { Spare parts, repair and } \\
\text { building materials for repair }\end{array}$ & 105.00 & 105.00 & 133.45 \\
\hline & Labor costs & 104.32 & 104.32 & 100.09 \\
\hline & Social benefits & 31.30 & 31.30 & 30.03 \\
\hline & Other prime costs & 25.00 & 25.00 & 33.36 \\
\hline \multirow[t]{4}{*}{ 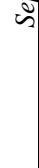 } & Works and services of third-parties & 90.00 & 90.00 & 83.41 \\
\hline & \begin{tabular}{|c|} 
Electricity \\
\end{tabular} & 19.00 & 19.00 & 23.36 \\
\hline & $\begin{array}{c}\text { The costs of organizing } \\
\text { production and its maintenance }\end{array}$ & 230.00 & 230.00 & 230.20 \\
\hline & Management costs & 130.00 & 130.00 & 129.28 \\
\hline & Total per month & $1,129.71$ & $1,129.71$ & $1,135.83$ \\
\hline & TOTAL production costs & $12,059.79$ & $12,334.43$ & $12,420.63$ \\
\hline
\end{tabular}

\begin{tabular}{|c|c|c|c|}
\hline \multicolumn{4}{|c|}{ 2. The estimation of the cost per unit of production } \\
\hline \multirow{3}{*}{ Parameter } & \multicolumn{2}{|c|}{ Plan } & Fact \\
\cline { 2 - 4 } & statement & adjustment & as of September \\
& March 20, 2018 & July 05, 2018 & 30,2018 \\
\hline Total harvest, dt & $35,974.67$ & $34,312.82$ & $32,380.81$ \\
\hline Cost of 1 centner, rub. & 335.23 & 359.47 & 383.58 \\
\hline
\end{tabular}


The possibility to automate the relevant calculations will allow timely providing the necessary information to the accounting process of the enterprise and the feedback function [18]. However, to increase the relevance of the information, it is proposed to combine the results of calculations of the adjusted planned cost of different crops according to the example in Table 2.

TABLE II. INFORMATION ON THE PLANNED COST OF GRAIN CROPS ACCORDING TO THE ADJUSTMENT OF JULY 05, 2018

\begin{tabular}{|c|c|}
\hline Crop & $\begin{array}{c}\text { Adjusted planned cost of } \\
1 \text { centner, rub. }\end{array}$ \\
\hline Spring wheat Agate; field 1-18 & 324.58 \\
\hline Spring wheat Lada; field 2-18 & 328.17 \\
\hline Spring barley Vicont; field 4-18 & 359.47 \\
\hline Winter wheat Viola; field 4-18 & 423.85 \\
\hline
\end{tabular}

In dairy cattle breeding, it is rational to group cows according to the month of their insemination [16]. In this case, the initial planned calculation of the cost of the offspring should be made according to the group of cows (or in more detail for each cow) at the end (or in the month) of insemination and in the month of dry period to adjust its value. The calculation of the actual cost of the offspring should be carried out at the end of the month of calving.

In this case, the planned cost of milk can be determined once at the beginning of each month also by the previously provided groups of cows, since the cost and volume of milk produced depends on the phases of the offspring formation: in months of milking after calving, in months of milking of pregnant cows, in months of the dry period [16].

Calculation is acceptable for each group of cows for each month of the pregnancy period (for groups of dairy pregnant cows, dry cows and in-calf heifers) or the milking period (for groups of milking cows), systematizing the information according to the example in Table 1. For groups of milk springers, it is necessary to foresee the distribution of costs for the production of the offspring and milk in the calculation algorithm [16] and to do this one should add the appropriate details to the register. The calculation results for different groups of animals are also recommended to be combined according to the example in Table 2 to provide the accounting process with the necessary data.

\section{CONCLUSION}

The specifics of economic activities with a long production cycle, agricultural production in particular, necessitates a serious adjustment of the applied cost accounting methods to increase the accuracy and efficiency of accounting information. The current level of development of technical means and computer programs allows implementing and optimizing the time-consuming processes of calculating values and detailing information to ensure the greatest accuracy and relevance of the resulting data. The development of methodological foundations for cost accounting of agricultural organizations involves:
- $\quad$ preparation of planned (initial) costing immediately before the start of the production cycle;

- compilation of provisory costing, involving the adjustment of the planned (expected) cost to a more accurate value before the estimated month of receipt of products from production;

- determination of the actual production cost of manufactured products at the end of the month in which the products of a particular type (group) are capitalized in full from production.

In addition to the improvement of the accuracy of accounting information about the planned and actual cost, the implementation of the proposed approach will allow optimization and efficiency of control functions and management decisions.

\section{References}

[1] Yu.N. Kudryashova, T.G. Lazareva, T.N. Makushina, Yu.V. Chernova, "The organization of management accounting as a mechanism to improve the efficiency of agricultural enterprises", BIO Web of Conf., vol. 17,2020 .

[2] N. Dechow, J. Mouritsen, "Enterprise resource planning systems, management control and the quest for integration", Account., Organizat. and Society, vol. 30, pp. 691-733, October-November 2005.

[3] S. Dierkes, D. Siepelmeye, "Production and cost theory-based material flow cost accounting", J. of Cleaner Product., vol. 235, pp. 483-492, October 2019.

[4] F.F. da Silva, V.C. de Medeiros, D.H.D. de Lima, C.V. da Lucena, "Gestão de custos dos processos e atividades: um estudo de caso em uma empresa de bovinocultura", Custos e @gronegócio on line, vol. 15, no. 2, pp. 87, Abr-Jun 2019.

[5] Z. Jiang, T. Zhou, H. Zhang, Ya. Wang, H. Cao, G. Tian, "Reliability and cost optimization for remanufacturing process planning", J. of Cleaner Product., vol. 135, pp. 1602-1610, November 2016.

[6] F. Zhang, B.A. Engel, Ch. Zhang, Sh. Guo, P. Guo, S. Wang, "Agricultural production planning approach based on interval fuzzy credibility-constrained bi-level programming and Nerlove supply response theory", J. of Cleaner Product., vol. 233, pp. 1158-1169, October 2019

[7] X. Zhao, K.V. Calvin, M.A. Wise, "The critical role of conversion cost and comparative advantage in modeling agricultural land use change", Climate Change Econ., pp. 44, 2020.

[8] M. Nelson, M.K. Maredia, "International agricultural research as a source of environmental impacts: challenges and possibilities", J. of Environmental Assessment Policy and Mana., vol. 09, no. 01, pp. 103-119, 2007.

[9] R.R. Palatnik, F. Eboli, A. Ghermandi, I. Kan, M. Rapaport-Rom, M. Shechter, "Integration of general and partial equilibrium agricultural landuse transformation for the analysis of climate change in the mediterranean", Climate Change Econ., vol. 02, no. 04, pp. 275-299, 2011.

[10] L. Bendlin, A. Souza, R. Rodrigues, D. Seidel, V. Bublitz, “Comparação da produção de ovos vermelhos x brancos: uma analise dos custos de produção, expectativas de retorno e riscos", Custos e @gronegócio on line, vol. 15, Edição Especial, pp. 202-239, Abr 2019.

[11] A.S. Zavgorodnyaya, I.G. Shashkova, V.S. Konkina, L.V. Romanova, E.I. Mashkova, M.Yu Pikushina, "Adaptive management of the agricultural enterprise in the conditions of environmental uncertainty", J. of Advan. Res. in Dynamical and Control Syst., no. 7, spec. iss., pp. 2022-2031, 2018.

[12] I.Yu. Bogdanchikov, N.V. Byshov, A.N. Bachurin, M.A. Esenin, M.A. Tkacheva, "The results of studying the effects of biological products on accelerating the decomposition of the not grain part of the crop", BIO Web of Conf. 2019, vol. 18, 2020. 
[13] E.P. Polikarpova, I.E. Mizikovskiy, "Preparing accounting information on costs for manufactured crop production", Custos e @ gronegócio on line, vol. 14, no. 4, pp. 149-165, 2018.

[14] C.S. Pletsch, C.E.F. Lavarda, L.F. Dallabona, G.R. de Oliveira, "Influência dos fatores contingenciais ambiente e estratégia nos sistemas de controle gerencial de uma cooperativa agropecuária", Custos e @ gronegócio on line, vol. 15, no. 1, pp. 229-253, Jan-Mar 2019.

[15] M. AGhali, "Production-planning horizon, production smoothing, and convexity of the cost functions", Int. J. of Product. Econ., vol. 81-82, pp. 67-74, January 2003.
[16] I.E. Mizikovskiy, E.P. Polikarpova, "Structuring the information field of production costs in order to form the prime cost of dairy cattle", Bull. for Professional Accountants, no 3, pp. 20-28, 2019.

[17] E.H.P. Vilela, A.S.T. Penedo, V.S. Pereira, "Pecuária leiteira no triângulo mineiro: uma análise dos custos de produção", Custos e @ gronegócio on line, vol. 15, no. 4, pp. 416-436, Out-Dez - 2019.

[18] G. Bakulina, G. Kalinina, I. Luchkova, M. Pikushina, A. Gracheva, "Transformation of the Accountancy Profession when Digitalization of Agriculture", BIO Web of Conf. 2019, vol. 18, 2020. 